\title{
EFFECT OF COMMUNICATION AND COORDINATION ON EMPLOYEE PERFORMANCE AT CV. AFIF KING TAMBAK DELI SERDANG
}

\author{
Dian Purnama Sari \\ Faculty of Economics and Business, Universitas Alwashliyah \\ J1. Garu II A, No. 93, Medan \\ E-mail:dianpurnama047@umsu.ac.id
}

\begin{abstract}
This study aims to determine whether communication and coordination both partially and simultaneously have a significant effect on employee performance at CV. Afif Raja Tambak Deli Serdang and how much influence he had. The method used in this study is a quantitative method with several tests, namely reliability analysis, classical assumption deviation test and linear regression. Based on the results of the primary data regression which was processed using SPSS 20, the following multiple linear regression equation was obtained: $Y=0.518+0.669 X 1+0.327 X 2$. Partially, the communication variable (X1) has a significant effect on employee performance $(Y)$ at $C V$. Afif Raja Tambak Deli Serdang. This means that the hypothesis in this study is accepted, as evidenced by the value of t count $>$ t table $(7.749>2.052)$. While the coordination variable $(X 2)$ has a significant effect on employee performance $(Y)$ at CV. Afif Raja Tambak Deli Serdang. This means that the hypothesis in this study is accepted, as evidenced by the value of t count > t table (3.389 > 2.052). Simultaneously, the variables of communication (X1) and coordination (X2) have a significant effect on employee performance $(Y)$ at CV. Afif Raja Tambak Deli Serdang. This means that the hypothesis in this study is accepted, as evidenced by the calculated $F$ value $>F$ table (340.584 > 3.35). Communication variables (X1) and coordination (X2) are able to contribute to the influence of employee performance variables at CV. Afif Raja Tambak Deli Serdang (Y) is $96.2 \%$ while the remaining $3.8 \%$ is influenced by other variables not examined in this study. From the conclusion above, The author suggests that employees and leaders should further improve and maintain existing coordination so that existing cooperation is more awake. Employees should work sincerely so that there are no company goals and employee needs are met by CV. Afif Raja Tambak Deli Serdang.
\end{abstract}

Keywords: Communication, Coordination and Performance

\section{INTRODUCTION}

Basically, a company does not only expect skilled human resources, but rather expects employees who are willing to work hard and are willing to achieve optimal work results. Human resources as one of the internal factors that play an important role in the success or failure of an organization in achieving its goals, so it needs to be directed through good human resource management. Through communication, a person is able to influence others to hear his policies, both direct and indirect communication. Communication is a means for establishing a relationship between a leader and subordinates, with communication there is a social relationship. A subordinate will feel happy if the leader wants to interact regularly in order to increase employee motivation and employee performance. If the employee's performance is good then so many benefits will be obtained by the company, especially the production of goods that continues to increase.

In the world of work, communication is needed in a company, therefore, communication has a big enough role in every work activity of an employee. By communicating activities in a company will not be hampered, because humans will relate to each other for the same purpose both between superiors and subordinates and fellow subordinates. In addition to communication, coordination also 
has a role in carrying out activities within an organization. Coordination is a cooperative attitude that requires other individuals to work well. Coordination will not go well if employees and other employees do not coordinate with each other in their work. Coordination is basically already formed in a written or unwritten rule. Implementing coordination by itself becomes a must for an employee to cooperate with other employees in terms of establishing cooperation for the goals to be achieved. Many employees do not achieve work targets or make mistakes at work due to lack of coordination with each other. Coordination must first be built by the leader who sets an example for subordinates to understand that coordination is very important in work activities. With coordination, it is hoped that harmony or harmony of all activities to achieve the expected goals. So that every company becomes balanced and in harmony in carrying out every job. Many employees do not achieve work targets or make mistakes at work due to lack of coordination with each other. Coordination must first be built by the leader who sets an example for subordinates to understand that coordination is very important in work activities. With coordination, it is hoped that harmony or harmony of all activities to achieve the expected goals. So that every company becomes balanced and in harmony in carrying out every job. Many employees do not achieve work targets or make mistakes at work due to lack of coordination with each other. Coordination must first be built by the leader who sets an example for subordinates to understand that coordination is very important in work activities. With coordination, it is hoped that harmony or harmony of all activities to achieve the expected goals. So that every company becomes balanced and in harmony in carrying out every job. With coordination, it is hoped that harmony or harmony of all activities to achieve the expected goals. So that every company becomes balanced and in harmony in carrying out every job. With coordination, it is hoped that harmony or harmony of all activities to achieve the expected goals. So that every company becomes balanced and in harmony in carrying out every job.

CV. Afif Raja Tambak Deli Serdang is a company engaged in providing goods such as report cards, books and school uniforms. In its activities, leaders and employees really need communication and coordination at work. But in fact communication and coordination in CV. Afif Raja Tambak Deli Serdang is not going well. Based on the author's initial observations with several employees that there is a lack of good communication between leaders and employees, such as communication tones that make misunderstandings, orders that are not given directly by superiors. Then the lack of coordination between warehouse employees and distribution employees regarding stock availability and the lack of employee responsibility in completing the assigned tasks. Departing from the problem above, the author's desire arises to raise further about communication and coordination in the form of a thesis proposal with the title: "The Effect of Communication and Coordination on Employee Performance in CV. Afif Raja Tambak Deli Serdang".

\section{RESEARCH METHOD}

The method used is a questionnaire method. This study uses a qualitative research approach. The place of this research in CV. Afif Raja Tambak Deli Serdang, having his address at Jalan Dusun Sedar, Tumpatan Village, Beringin District, Deli Serdang Regency. This research starts from AprilSeptember 2021. The population of this study is 30 respondents. The variables used in this study include communication and coordination as independent variables and employee performance as the dependent variable. The sampling technique in this study used data analysis techniques in this study including statistical test analysis and linear regression.

\section{RESULTS AND DISCUSSION}

Regression analysis is used to determine whether there is an influence between variables. The following is a summary of the results of simple and multiple regression analysis and path analysis. 
Table 1. Statistical Test Results

\begin{tabular}{|c|c|c|c|c|c|c|c|}
\hline \multirow{2}{*}{ Model } & \multicolumn{2}{|c|}{$\begin{array}{c}\text { Unstandardized } \\
\text { Coefficients }\end{array}$} & \multirow{2}{*}{\begin{tabular}{|c|}
$\begin{array}{c}\text { Standardized } \\
\text { Coefficients }\end{array}$ \\
Beta \\
\end{tabular}} & \multirow{2}{*}{$\mathrm{t}$} & \multirow{2}{*}{ Sig. } & \multicolumn{2}{|c|}{ Collinearity Statistics } \\
\hline & B & Std. Error & & & & Tolerance & VIF \\
\hline (Constant) & .518 & 1,688 & & .307 & .761 & & \\
\hline $\begin{array}{l}\text { Communica } \\
\text { tion }\end{array}$ & 669 & .086 & .696 & 7.749 & .000 & .175 & 5,713 \\
\hline $\begin{array}{l}\text { Coordinatio } \\
\mathrm{n}\end{array}$ & .327 & .097 & .304 & 3.389 & .002 & .175 & 5,713 \\
\hline
\end{tabular}

a. Dependent Variable: Performance

Source: SPSS Output Version 20 (2021)

Based on table 1 it can be seen that each tolerance value is $0.175>0.1$ and the VIF value is $5.713<10$. These results indicate that there is no multicollinearity in the regression model.

Table 2. Results of Simple Linear Regression Analysis

\begin{tabular}{|c|c|c|c|c|c|c|c|}
\hline \multirow[t]{2}{*}{ Model } & \multicolumn{2}{|c|}{$\begin{array}{c}\text { Unstandardized } \\
\text { Coefficients }\end{array}$} & \multirow{2}{*}{\begin{tabular}{|c|}
$\begin{array}{c}\text { Standardized } \\
\text { Coefficients }\end{array}$ \\
Beta \\
\end{tabular}} & \multirow[t]{2}{*}{$\mathrm{t}$} & \multirow[t]{2}{*}{ Sig. } & \multicolumn{2}{|c|}{ Collinearity Statistics } \\
\hline & B & Std. Error & & & & Tolerance & VIF \\
\hline (Constant) & .518 & 1,688 & & .307 & .761 & & \\
\hline $\begin{array}{l}\text { Communica } \\
\text { tion }\end{array}$ & .669 & .086 & .696 & 7.749 & .000 & .175 & 5,713 \\
\hline $\begin{array}{l}\text { Coordinatio } \\
\mathrm{n}\end{array}$ & .327 & .097 & .304 & 3.389 & .002 & .175 & 5,713 \\
\hline
\end{tabular}

a. Dependent Variable: Performance

Source: SPSS Output Version 20 (2021)

Based on table 2 , it can be seen that the constant value (a) $=0.518$ indicates a constant value, where if the communication variable $(\mathrm{X} 1)$ and coordination variable $(\mathrm{X} 2)=0$ then the employee performance variable $(Y)=0.518$. The communication variable regression coefficient $(X 1)=0.669$ indicates that communication has a positive effect on employee performance, if communication (X1) is increased by one unit then employee performance $(\mathrm{Y})$ will also increase by 0.669 . The regression coefficient of the coordination variable $(\mathrm{X} 2)=0.327$ indicates that the coordination variable has a positive effect on employee performance, if coordination (X2) is increased by one unit, the employee's performance $(\mathrm{Y})$ will also increase by 0.327 .

\section{CONCLUSION}

From the research conducted, the following results were found: 1) Partially, the communication variable (X1) had a significant effect on employee performance (Y) at CV. Afif Raja Tambak Deli Serdang. This means that the hypothesis in this study is accepted, as evidenced by the value of $t$ count $>t$ table $(7.749>2.052)$. While the coordination variable $(X 2)$ has a significant effect on employee performance (Y) at CV. Afif Raja Tambak Deli Serdang. This means that the hypothesis in this study is accepted, as evidenced by the value of $t$ count $>t$ table $(3.389>2.052) .2$ ) Simultaneously, communication (X1) and coordination (X2) variables have a significant effect on employee performance (Y) at CV. Afif Raja Tambak Deli Serdang. This means that the hypothesis in this study is accepted, as evidenced by the calculated $\mathrm{F}$ value $>\mathrm{F}$ table $(340.584>3.35)$. 
From the results of this study, suggestions can be given first, employees and leaders should improve and maintain existing coordination so that existing cooperation is more maintained. Second, employees should work sincerely so that there are no company goals and employee needs are met by CV. Afif Raja Tambak Deli Serdang.

\section{REFERENCE}

Anwar Prabu Mangkunegara, 2013. Manajemen Personalia. Penerbit Ghalia Indonesia. Jakarta.

Arikunto Suharsimi, 2016. Manajemen Penelitian. Cetakan ke X. Penerbit PT. Rineka Cipta. Jakarta.

Duwi Priyatno. 2008. 5 Jam Belajar Olah Data Dengan SPSS 17. Penerbit Andi. Yogyakarta.

Ety Rochaety, dkk. 2009. Metode Penelitian Bisnis Dengan Aplikasi SPSS. Penerbit Mitra Wacana Media. Jakarta.

Gibson, Ivancevich, \& Donnely. 2009. Organisasi: Perilaku, Struktur, Proses, Ed Revisi, Penerbit Erlangga. Jakarta.

GR Terry. 2000. Manajemen Personalia. Jilid 1, Edisi Ke-6, Penerbit Erlangga, Jakarta.

Hamali A Y. 2018. Pemahaman Manajemen Sumber Daya Manusia Strategi Mengelola Karyawan. Cetakan ke II. Penerbit CAPS (Centre for Academic Publishing Service). Yogyakarta.

Handayaningrat, 2005. Pengantar Studi Ilmu Administrasi dan Managemen. Cetakan Keenam. PT. Gunung Agung. Jakarta.

Ircham Machfoedz. 2010. Metodologi Penelitian (Kuantitatif \& Kualitatif). Penerbit Fitramaya. Yogyakarta.

Joko Purwanto. 2011. Komunikasi Bisnis, Ed 3, Penerbit Erlangga. Jakarta.

Joko Subagyo. 2007. Metode Penelitian Dalam Teori dan Praktek. Penerbit Rineka Cipta. Jakarta.

Laksarini Riyana Fitri. 2018. Pengaruh Semangat Kerja Terhadap Kinerja Karyawan Non Media di Rumah Sakit Islami Siti Aisyah Madiun Tahun 2018. STIKES Bhakti Husada Mulia. Madiun.

Malayu SP Hasibuan, 2001. Manajemen Sumber Daya Manusia. Edisi Revisi, Penerbit BumiAksara. Jakarta.

Manullang, 2001, Dasar-Dasar Manajemen, Gadjah Mada University Press, Yogyakarta.

Mifta Thoha. 2011. Perilaku Organisasi. Penerbit Rajawali Pers. Jakarta.

Moh. Nazir. 2014. Metode Penelitian. Penerbit Ghalia Indonesia. Bogor.

Mudrajad Kuncoro. 2013. Metode Riset Untuk Bisnis dan Ekonomi. Penerbit Erlangga, Jakarta.

Rahmad Agus. 2014. Pengaruh Komunikasi Terhadap Efektivitas Koordinasi Pegawai Pada Badan Pemberdayaan Perempuan, Anak Dan Keluarga Berencana (BPPA-KB) Kabupaten Serdang Bedagai. STIE. BM. Serdang Bedagai. 
Sahat Simanjuntak. 2016. Pengaruh Kelancaran Koordinasi Terhadap Efektivitas Kerja Pegawai Pada Dinas Kehutanan Kabupaten Deli Serdang. Universitas Sumatera Utara. Medan.

Sugiyono, 2017. Metode Penelitian Kuantitatif, Kualitatif dan R\&D. Penerbit CV. Alfabeta. Bandung.

Sutrisno Edy. 2019. Manajemen Sumber Daya Manusia. Edisi I. Penerbit Prenadamedia Group. Jakarta.

Syaiful Bahri, 2018. Metodologi Penelitian Bisnis Lengkap dengan Teknik Pengolahan Data SPSS. Edisi I. Penerbit CV. Andi Offset. Yogyakarta.

T. Hani Handoko. 2003. Manajemen. Edisi ke- 2 Cetakan kedelapan belas. Penerbit BPFEYogyakarta.

Winardi, 2000, Azas-Azas Manajemen, Mandar Maju, Bandung.

Yoyo Sudaryo. 2018. Manajemen Sumber Daya Manusia. Penerbit Andi. Yogyakarta. 